\title{
Faktor-faktor yang Memengaruhi Kualitas Laporan Keuangan Pemerintah Daerah di Kabupaten Banyuasin dengan Sistem Pengendalian Internal Pemerintah sebagai Variabel Moderasi
}

\author{
Reny Aziatul Pebriani ${ }^{1)}$ \\ ${ }^{1)}$ Program Studi Akuntansi, Universitas Indo Global Mandiri \\ Jalan Jenderal Sudirman No. 629 KM. 4 Palembang Kode pos 30129 \\ Email : renyaziatul@uigm.ac.id ${ }^{1)}$
}

\begin{abstract}
The aim of this study is to determine and analyse the effect of human resource competence, utilization of information technology, the implementation of government accounting standards, the role of internal audit on the quality of local government financial statement and its effect on regional work unit that is moderated by government internal control system in Banyuasin. The method used is descriptive and explanatory survey using 108 respondents. The data analysis method used in this study is multiple regression analysis and the moderating effect is tested using Moderated Regression Analysis through SPSS 23. The results show that human resource competence, utilization of information technology, the implementation of government accounting standards, the role of internal audit have simultaneous and significant effect on the quality of local government financial statement. However, when it is tested partially, the implementation of government accounting standards is found to be insignificant. Furthermore, the role of internal that is moderated by government internal control system does not have significant effect on the quality of local government financial statement. The results indicate that to improve the quality of local government financial statement, continues improvement on government internal control system is needed. the government needs to improve the quality of internal audit to improve the role of supervision, coaching, monitoring, and review of financial statements so as to be able to work professionally, objectively and independently.
\end{abstract}

Keywords : Human resource competence, utilization of information technology, government internal control system, Government financial statement quality.

\begin{abstract}
ABSTRAK
Tujuan dari penelitian ini adalah untuk mengetahui dan menganalisis besarnya pengaruh kompetensi SDM, pemanfaatan TI, penerapan SAP, peran Audit Internal secara parsial maupun bersama-sama terhadap kualitas LKPD dan pengaruhnya yang dimoderasi oleh SPIP pada Organisasi Perangkat Daerah (OPD) Kabupaten Banyuasin. Metode yang digunakan adalah metode deskriptif dan survey eksplanatori dengan ukuran sampel 108 responden. Metode analisis data yang digunakan yaitu Regresi Linier Berganda dengan pengujian variabel moderasi menggunakan MRA (Moderated Regression Analysis) dan pengolahan data menggunakan software SPSS 23. Hasil penelitian ini membuktikan bahwa kompetensi SDM, pemanfaatan TI, penerapan SAP, peran Audit Internal secara bersama-sama berpengaruh dan signifikan terhadap kualitas LKPD, namun secara parsial penerapan SAP tidak berpengaruh secara signifikan. Kemudian secara moderasi variabel peran audit internal yang dimoderasi oleh SPIP tidak berpengaruh signifikan terhadap kualitas LKPD. Kesimpulan penelitian ini berhasil menemukan bahwa untuk meningkatkan kualitas LKPD studi kasus pada OPD di Kabupaten Banyuasin, diperlukan upaya perbaikan dan peningkatan secara berkelanjutan terhadap SPIP dalam rangka mempertahankan dan meningkatkan kualitas LKPD, pemerintah perlu meningkatkan kualitas audit internal guna meningkatkan peran pengawasan, pembinaan, pemantauan, dan reviu laporan keuangan sehingga mampu bekerja secara profesional, obyektif dan independen.
\end{abstract}

Kata kunci : Kompetensi SDM, Pemanfaatan TI, SPIP, Kualitas LKPD 


\section{Pendahuluan}

Era reformasi keuangan sektor publik menjadi fenomena baru dan berdampak meningkatnya tuntutan masyarakat akan suatu pemerintahan yang transparan dan akuntabel. Paradigma baru tersebut mewajibkan setiap satuan kerja termasuk pemerintah daerah mempertanggungjawabkan keuangan daerah secara transparan kepada publik sebagaimana diatur dalam Undang-Undang Nomor 17 Tahun 2003 tentang Keuangan Negara dan Undang-Undang Nomor 1 tahun 2004 tentang Perbendaharaan Negara. Pertanggungjawaban keuangan pemerintah daerah dilakukan dan disampaikan dalam bentuk laporan keuangan.

Hasil audit BPK terhadap laporan keuangan pemerintah daerah (LKPD) seluruh Indonesia menunjukkan masih banyak pemerintah daerah yang belum memperoleh opini WTP. Untuk tahun pelaporan 2015, BPK mencatat hanya 58 persen atau 312 LKPD yang memperoleh opini WTP. Sementara itu LKPD lainnya tercatat memperoleh opini WDP sebanyak 187 LKPD, TMP sebanyak 30 LKPD, dan masih ada 4 LKPD yang memperoleh opini TW (Badan Pemeriksa Keuangan RI, 2016). Namun secara keseluruhan pengelolaan keuangan daerah semakin baik setiap tahun, hal ini ditandai dengan terus meningkatnya persentase opini WTP, penurunan WDP dan TMP. Dibandingkan dengan tahun 2014, LKPD yang mendapat opini WTP mengalami kenaikan dari 47 persen menjadi 58 persen. Kenaikan kualitas ini didukung oleh upaya pemerintah daerah memperbaiki kelemahan yang terjadi setiap tahunnya.

Perbaikan yang dicapai oleh entitas pemerintah daerah khususnya di Kabupaten Banyuasin dalam menyajikan suatu laporan keuangan yang wajar sesuai dengan prinsip yang berlaku merupakan gambaran bahwa setiap pemerintah daerah terus melakukan perbaikan terhadap Laporan Keuangan Pemerintah Daerah (LKPD). Kabupaten Banyuasin telah berupaya untuk menyusun laporan keuangan berdasarkan Standar Akuntansi Pemerintah (SAP) yang berlaku, sehingga kualitas yang dihasilkan dari laporan keuangan daerah tersebut dapat meningkat dan berkualitas. Hal ini dapat dilihat dalam Ikhtisar Hasil Pemeriksaan (IHPS) I Tahun 2016 (IHPS BPK RI periode 2011-2016) LKPD Kabupaten Banyuasin mendapat hasil opini BPK Wajar Tanpa Pengecualian (WTP). Hal ini membuktikan bahwa Pemerintah Kabupaten Banyuasin telah berhasil menyusun laporan keuangan dengan baik dan penggunaan anggaran yang baik dan tepat sasaran.

Kualitas Laporan Keuangan Pemerintah Daerah (LKPD) dipengaruhi oleh beberapa faktor, diantaranya kompetensi SDM. Pengelolaan keuangan daerah yang sehat dalam rangka menciptakan good governance juga harus diikuti dengan SDM yang kompeten. Namun sudah menjadi permasalahan umum di instansi pemerintah daerah bahwa untuk penataan personil, seringkali dilakukan tidak sesuai dengan kebutuhan baik secara kuantitas maupun kualitas (cakap). Hal ini sangat berkaitan dengan pengembangan organisasi yang hanya mempertimbangkan kewenangan sementara kualitas SDM yang ada belum memenuhi kompetensi yang seharusnya dipenuhi. SDM adalah pilar penyangga utama sekaligus penggerak roda organisasi dalam usaha mewujudkan visi dan misi tujuannya (Sudarmanto, 2009).

Pemanfaatan teknologi informasi (TI) merupakan faktor selanjutnya yang memengaruhi kualitas LKPD. Teknologi dipandang sebagai alat yang digunakan oleh individu untuk menyelesaikan tugas-tugasnya. Kewajiban pemanfaatan teknologi informasi oleh Pemerintah Pusat dan Pemerintah Daerah diatur dalam Peraturan Pemerintah No. 65 Tahun 2010 tentang Sistem Informasi Keuangan Daerah. Secara umum telah banyak diketahui manfaat yang ditawarkan oleh suatu teknologi informasi antara lain kecepatan pemrosesan transaksi dan penyiapan laporan, keakuratan perhitungan, penyimpanan data dalam jumlah besar, biaya pemrosesan yang lebih rendah, kemampuan multiprocessing (Wahana Komputer, 2003).

Standar Akuntansi Pemerintah (SAP) merupakan prinsip-prinsip akuntansi yang diterapkan dalam menyusun dan menyajikan Laporan Keuangan Pemerintah Daerah (LKPD) yang mempunyai kekuatan hukum dalam upaya meningkatkan kualitas LKPD di Indonesia (Kawedar, 2010). SAP mewajibkan setiap entitas pelaporan termasuk pemerintah daerah untuk melaporkan upaya-upaya yang telah dilakukan serta hasil yang dicapai dalam pelaksanaan kegiatan secara sistematis dan terstruktur pada suatu periode pelaporan untuk kepentingan akuntabilitas, manajemen, transparansi, keseimbangan antara generasi dan evaluasi kinerja. Penerapan SAP yang benar dan pemahaman yang baik terhadap akuntansi keuangan daerah oleh pengelola keuangan pada Organisasi Perangkat Daerah (OPD) tentunya akan meningkatkan kualitas laporan keuangan dan mengandung informasi yang berguna.

Selanjutnya untuk menilai ketepatan pelaksanaan kebijakan organisasi dan melakukan tindakan koreksi jika terdapat penyimpangan, maka diperlukan peran pengawas/audit internal agar organisasi dapat mencapai tujuan secara efisien dan efektif khususnya yang berkaitan dalam LKPD. Peran audit internal tentunya mengawasi dan mengevaluasi prosedur, kebijakan dan laporan keuangan yang sudah dihasilkan suatu instansi, agar pengelolaan keuangan berjalan sesuai dengan ketentuan yang berlaku.

Hal terakhir yang memengaruhi kualitas laporan keuangan adalah SPI pemerintah itu sendiri. Pada tahun 2008 pemerintah mengeluarkan Peraturan Pemerintah Nomor 60 tahun 2008 tentang Sistem Pengendalian Internal Pemerintah (SPIP). PP tersebut menyebutkan bahwa tujuan SPIP bertujuan untuk memberikan keyakinan yang memadai bagi tercapainya efektivitas dan efisiensi pencapaian tujuan penyelenggaraan pemerintahan negara, keandalan Laporan Keuangan, pengamanan aset negara, dan ketaatan terhadap peraturan perundang-undangan. Dengan mengoptimalkan SPIP diharapkan pengendalian internal 
semakin efektif sehingga dapat memediasi dalam mengatasi permasalahan rendahnya kualitas LKPD.

Penelitian ini merupakan pengembangan model dari beberapa penelitian terdahulu, sehingga penelitian ini dilakukan kembali untuk meneliti faktor-faktor yang memengaruhi kualitas laporan keuangan pemerintah daerah dengan SPIP sebagai variabel moderasi, dimana faktor-faktor yang akan diuji meliputi kompetensi SDM, pemanfaatan TI, penerapan SAP, peran Audit Internal, dan SPIP dengan objek penelitian bagian keuangan/tata usaha keuangan di Kabupaten Banyuasin.

\section{A. Tinjauan Pustaka}

1. Teori Stewardship

Teori Stewardship sering disebut sebagai teori pengelolaan (penatalayanan) dengan 8 asumsi-asumsi dasar (fundamental assumptions of stewardship theory).

Pertimbangan penggunaan teori Stewardship sehubungan dengan masalah penelitian ini :

a. Manajemen sebagai stewards (pelayan/penerima amanah/pengelolah).

b. Pendekatan governance menggunakan sosiologi dan psikologi.

c. Model Manusia, berperilaku kolektif untuk kepentingan organisasi.

d. Motivasi pimpinan sejalan dengan tujuan principals.

e. Kepentingan manajer-principal adalah konvergensi.

f. Struktur berupa fasilitasi dan pemberdayaan.

g. Sikap pemilik mempertimbangkan risiko.

h. Hubungan principals-manajemen saling percaya.

2. Kualitas Laporan Keuangan Pemerintah Daerah

Laporan keuangan pemerintah ditujukan untuk memenuhi tujuan umum pelaporan keuangan, namun tidak untuk memenuhi kebutuhan khusus pemakaiannya. Disamping penyusunan laporan keuangan bertujuan umum, entitas pelaporan dimungkinkan untuk menghasilkan laporan keuangan yang disusun untuk kebutuhan khusus. (Mardiasmo, 2009) mengatakan bahwa lembaga pemerintah dituntut untuk dapat membuat laporan keuangan eksternal yang meliputi laporan keuangan formal seperti laporan surplus defisit, laporan realisasi anggaran, laporan arus kas, dan neraca serta kinerja yang dinyatakan dalam ukuran finansial dan non finansial. Pelaporan keuangan dihasilkan dari proses akuntansi keuangan dan merupakan media untuk mengkomunikasikan informasi keuangan kepada pihakpihak eksternal yang menaruh perhatian kepada badan atau organisasi pembuat laporan serta aktivitas-aktivitas.

\section{Kompetensi Sumber Daya Manusia}

Kompetensi merupakan dasar seseorang untuk mecapai kinerja tinggi dalam menyelesaikan kinerjanya. Sumber daya manusia yang tidak memiliki kompetensi tidak akan dapat menyelesaikan pekerjaanya secara efisien, efektif, dan ekonomis. Dalam hal ini pekerjaan yang dihasilkan tidak akan tepat waktu dan terdapat pemborosan waktu serta tenaga. Dengan adanya kompetensi sumber daya manusia maka waktu pembuatan laporan keuangan akan dapat dihemat. Hal ini karena sumber daya manusia tersebut telah memiliki pengetahuan dan pemahaman mengenai hal-hal yang harus dikerjakan, sehingga laporan keuangan yang disusun dapat diselesaikan dan disajikan tepat pada waktunya. Semakin cepat laporan keuangan disajikan maka akan semakin baik dalam hal pengambilan keputusan (Mardiasmo, 2005).

Pengelolaan keuangan daerah yang baik harus memiliki SDM yang berkualitas yang didukung dengan latar belakang pendidikan akuntansi, sering mengikuti pendidikan dan pelatihan, serta memiliki pengalaman dibidang keuangan sehingga untuk menerapkan sistem akuntansi, SDM yang berkompeten tersebut akan mampu memahami logika akuntansi dengan baik.

4. Pemanfaatan Teknologi Informasi

Teknologi informasi meliputi segala cara atau alat yang terintegrasi yang digunakan untuk menjaring data, mengolah dan mengirimkan atau menyajikan secara elektronik menjadi informasi dalam berbagai format yang bermanfaat bagi pemakainya. Thompson, et al (1994) mendefinisikan pemanfaatan teknologi sebagai manfaat yang diharapkan oleh pengguna sistem informasi dalam melaksanakan tugasnya dimana pengukurannya berdasarkan pada intensitas pemanfaatan, frekuensi pemanfaatan dan jumlah aplikasi atau perangkat lunak yang digunakan.

\section{Penerapan Standar Akuntansi Pemerintah}

Standar Akuntansi Pemerintahan (SAP) menurut Peraturan Pemerintah Nomor 71 tahun 2010 adalah prinsip-prinsip akuntansi yang diterapkan dalam menyusun dan menyajikan Laporan Keuangan Pemerintah, yang terdiri atas Laporan Keuangan Pemerintah Pusat (LKPP) dan Laporan Keuangan Pemerintah Daerah (LKPD), dalam rangka transparansi dan akuntabilitas penyelenggaraan akuntansi pemerintahan, serta peningkatan kualitas LKPP dan LKPD. SAP dinyatakan dalam bentuk Pernyataan Standar Akuntansi Pemerintahan (PSAP), yaitu SAP yang diberi judul, nomor, dan tanggal efektif. Selain itu, SAP juga dilengkapi dengan Kerangka Konseptual Akuntansi Pemerintahan.

6. Peran Audit Internal

Peran audit internal berkaitan dengan kualitas laporan keuangan dalam pengelolaan dan tanggung jawab keuangan negara tersirat di dalam pasal 9 (1) UU No. 15 Tahun 2004, bahwa dalam menyelenggarakan pemeriksaan pengelolaan dan tanggung jawab keuangan negara, BPK dapat memanfaatkan hasil pemeriksaan Aparat Pengawasan Internal Pemerintah (APIP). Berdasarkan PP No. 60 Tahun 2008 tentang SPIP, Peran Audit Internal tidak terbatas pada pengawasan keuangan tetapi mendapat peran baru untuk melakukan pembinaan/konsultasi disamping melakukan review laporan keuangan pemerintah. Dalam pelaksanaan tugasnya, pengawasan internal tersebut berkaitan erat dengan sistem pengawasan keuangan negara. Sistem pengawasan terdiri dari lembaga-lembaga pengawasan fungsional yang disusun berlapis-lapis. Lembaga pengawasan terdiri dari internal atau dan lembaga eksternal atau aparat pengawasan eksternal pemerintah. APIP meliputi BPKP yang berada dibawah Presiden dan 
Inspektorat Jenderal Departemen yang berada di bawah departemen.

Berdasarkan uraian di atas maka dapat disimpulkan bahwa peran audit internal yang mendukung penelitian diambil adalah dimensi-dimensi sebagai berikut: 1) independensi, 2) kemampuan profesional, 3) lingkup pekerjaan, 4) pelaksanaan kegiatan pemeriksaan, dan 5) pengelolaan bagian pemeriksaan internal.

7. Sistem Pengendalian Internal Pemerintah

Berdasarkan Peraturan Pemerintah RI nomor 60 tahun 2008 tentang sistem pengendalian internal pemerintah, Sistem Pengendalian Internal Pemerintah adalah proses yang integral pada tindakan dan kegiatan yang dilakukan secara terus menerus oleh pimpinan dan seluruh pegawai untuk memberikan keyakinan memadai atas tercapainya tujuan organisasi melalui kegiatan yang efektif dan efisien, keandalan pelaporan keuangan, pengamanan aset negara, dan ketaatan terhadap peraturan perundang-undangan.

SPIP dirancang untuk memberikan jaminan bahwa tujuan organisasi dapat dicapai melalui efisiensi dan efektivitas operasi, reabilitas penyajian laporan keuangan yang dapat dipercaya, dan ketaatan terhadap undangundang serta kebijakan yang berlaku.

Berkaitan dengan pengaruh pengendalian intern terhadap kualitas laporan keuangan, pengaruh pengendalian intern secara langsung ataupun tidak langsung akan terpapar dalam laporan keuangan. Jika pengendalian intern suatu organisasi baik, maka akan baik pula yang hasil yang didapat, namun jika pengendalian internnya buruk maka akan buruk pula hasilnya. Hal tersebut selaras dengan yang ditulis oleh Tuanakotta (2013) dalam buku Audit Berbasis ISA (International Standar on Auditing) yang menyatakan bahwa pengendalian intern bertujuan membuat laporan keuangan bebas dari salah saji yang material, yang disebabkan oleh kesalahan (error) maupun kecurangan (fraud).

8. Kerangka Pemikiran

Penelitian ini bertujuan untuk mengetahui ada atau tidaknya pengaruh hubungan antara variabel terikat yaitu nilai informasi pelaporan keuangan dengan variabel bebas yaitu kompetensi sumber daya manusia, pemanfaatan teknologi informasi, penerapan standar akuntansi pemerintah, peran audit internal, dan sistem pengendalian internal sebagai moderasi terhadap kualitas laporan keuangan pemerintaah daerah.

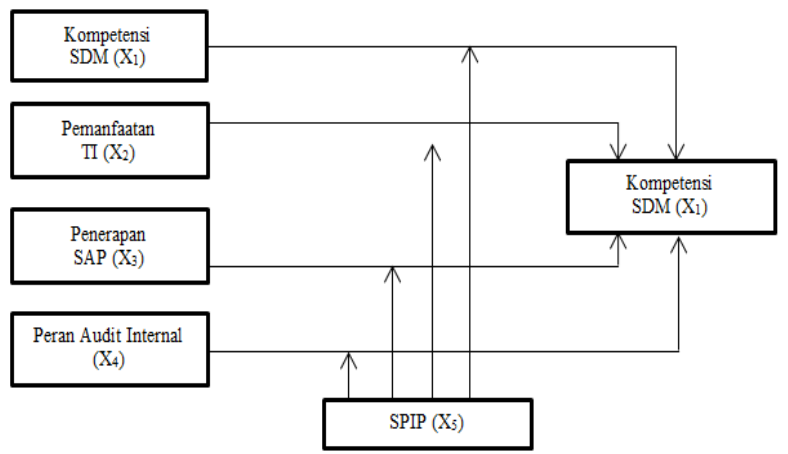

Gambar 1. Kerangka Pikir Penelitian
9. Hipotesis

Sesuai model penelitian di atas maka dapat dirumuskan hipotesis penelitian sebagai berikut:

a. Kompetensi SDM, pemanfaatan TI, penerapan SAP, dan peran Audit Internal berpengaruh positif dan signifikan terhadap kualitas LKPD

b. Kompetensi SDM, pemanfaatan TI, penerapan SAP, dan peran Audit Internal berpengaruh positif dan signifikan terhadap kualitas LKPD yang dimoderasi SPIP.

\section{B. Metode Penelitian}

1. Jenis Dan Sumber Data

a. Data Primer

Data dikumpulkan secara khusus untuk menjawab pertanyaan penelitian yang sesuai dengan keinginan peneliti yaitu dengan skor variabel yang berkaitan dengan jawaban responden terhadap kuisioner yang dibagikan meliputi kompetensi SDM, pemanfaatan TI, penerapan SAP, peran audit internal, SPIP dan kualitas LKPD. Data primer diperoleh melalui pengumpulan data kuisioner.

b. Data Sekunder

Data sekunder pada penelitian ini diperoleh peneliti secara tidak langsung melalui perantara (diperoleh dan dicatat oleh pihak lain). Data sekunder yang diperoleh berupa bukti, catatan, atau laporan historis yang telah tersusun dalam arsip (data dokumenter) yang dipublikasikan dan yang tidak dipublikasikan, penelusuran melalui internet berupa kondisi umum lokasi penelitian, visi dan misi, tugas pokok dan fungsi instansi, undang-undang, peraturan pemerintah, peraturan daerah mengenai pengelolaan keuangan daerah dan data lain yang memiliki relevansi dengan kajian yang akan dibahas.

2. Metode Pengumpulan data

Metode yang digunakan dalam penelitian ini adalah metode survei, dimana informasi dan data yang diperoleh secara langsung dari responden menggunakan teknik kuisioner (questionnares). Kuisioner yang diajukan kepada 108 responden pada OPD di Kabupaten Banyuasin yang disusun berdasarkan indikator yang telah disusun pada operasionalisasi variabel guna mendapat jawaban sebagai data yang akan diolah dan dibuat dalam bentuk menggunakan skala Likert.

3. Metode Analisis Data

Pengujian hipotesis dilakukan dengan analisis multivariate menggunakan MRA (moderated regression analysis) dengan persamaan matematis pada penelitian ini sebagai berikut :

Uji Analisis Regresi Berganda

Persamaan I $=\mathrm{LKPD}=\beta 0+\beta 1 \mathrm{SDM}+\beta 2 \mathrm{TI}+\beta 3 \mathrm{SAP}$ $+\beta 4 \mathrm{AI}+\mathrm{e}$

Uji Moderated Regression Analysis (MRA)

Persamaan II $=$ LKPD $=\beta 0+\beta 1 \mathrm{SDM}+\beta 2 \mathrm{SPIP}+$ $\beta 3$ SDM.SPIP + e

Persamaan III $=$ LKPD $=\beta 0+\beta 1 \mathrm{TI}+\beta 2$ SPIP + $\beta 3$ TI.SPIP $+\mathrm{e}$

Persamaan IV $=$ LKPD $=\beta 0+\beta 1 \mathrm{SAP}+\beta 2 \mathrm{SPIP}+$ $\beta 3$ SAP.SPIP + e 
Persamaan V $=\mathrm{LKPD}=\beta 0+\beta 1 \mathrm{AI}+\beta 2 \mathrm{SPIP}+$ $\beta 3$ AI.SPIP + e

Keterangan :

LKPD : Kualitas LKPD

SDM : Kompetensi SDM

TI : Pemanfaatan TI

SAP : Penerapan SAP

AI : Peran Audit Internal

SPIP : Sistem Pengendalian Internal Pemerintah

SDM.SPIP : Interaksi antara kompetensi SDM dan SPIP

TI.SPIP : Interaksi antara pemanfaatan TI dan SPIP

SAP.SPIP : Interaksi antara penerapan SAP dan SPIP

AI.SPIP : Interaksi antara peran audit inernal dan SPIP $\beta 0$ : Nilai konstanta

$\beta 1, \beta 2, \beta 3, \beta 4$, : Koefisien regresi variabel $X$

e : Error/ Residual

\section{Hasil dan Pembahasan}

A. Analisis Regresi Linear Berganda

Berdasarkan hasil perhitungan maka dibentuk suatu model persamaan regresi sebagai berikut :

LKPD $=-2,958+0,568 \mathrm{SDM}+0,364 \mathrm{TI}+0,119 \mathrm{SAP}+$ $0,194 \mathrm{AI}+\mathrm{e}$

Pada persamaan tersebut menunjukkan angka yang signifikan pada variabel kompetensi SDM (X1), pemanfaatan TI (X2), dan peran Audit Internal (X4), sedangkan untuk variabel penerapan SAP (X3) tidak menunjukkan angka yang signifikan. Adapun interprestasi dari persamaan tersebut adalah :

1. $\mathrm{b} 0=-2,958$

Nilai konstanta ini menunjukkan bahwa apabila tidak ada variabel kompetensi SDM, penerapan TI, penerapan SAP, dan peran audit internal, maka kualitas LKPD (Y) tidak akan meningkat sebesar 2,958.

2. $\mathrm{b} 1=0,568$

Nilai koefisien kompetensi SDM sebesar 0,568, artinya jika kompetensi SDM meningkat maka kualitas LKPD akan meningkat sebesar 0,568 atau 56,8 persen.

3. $\mathrm{b} 2=0,364$

Nilai koefisien pemanfaatan TI 0,364 , artinya jika pemanfaatan TI meningkat, maka kualitas LKPD akan meningkat sebesar 0,364 atau 36,4 persen.

4. $b 3=0,119$

Nilai koefisien penerapan SAP sebesar 0,119, artinya jika penerapan SAP meningkat, maka kualitas LKPD akan meningkat sebesar 0,119 atau 11,9 persen.

5. $\mathrm{b} 4=0,194$

Nilai koefisien peran audit internal sebesar 0,194, artinya jika peran audit internal meningkat, maka kualitas LKPD akan meningkat sebesar 0,194 atau 19,4 persen.

\section{B. Uji Moderated Regression Analysis (MRA)}

Persamaan II $=$ LKPD $=a+b 1 S D M+b 2 S P I P+$ b3SDM.SPIP + e

Hasil uji hipotesis menunjukkan bahwa diketahui nilai $\mathbf{t}_{\text {hitung }}$ untuk variabel kompetensi $\operatorname{SDM}\left(\mathrm{X}_{1}\right)$ yang dimoderasi SPIP (Z) sebesar 4,168 sedangkan, nilai $\mathbf{t}_{\text {tabel }}$ dengan taraf nyata (a) sebesar $0,05(5 \%)$ serta $\mathrm{df}=\mathrm{n}-\mathrm{k}-1$ $=108$ adalah sebesar 1,659. Jadi dapat disimpulkan bahwa Ha diterima dan Ho ditolak karena, nilai $\mathbf{t}_{\text {hitung }}$ $(4,168)>t_{\text {tabel }}(1,659)$.

Hasil uji hipotesis individual untuk variabel kompetensi SDM $\left(\mathrm{X}_{1}\right)$ menunjukkan bahwa variabel tersebut tidak berpengaruh secara signifikan terhadap variabel terikat (Y) yang dimoderasi variabel SPIP (Z). Hal ini digambarkan dengan nilai $\mathrm{R}^{2}$ pada regresi pertama sebesar 0,584 atau 58,4 persen sedangkan setelah ada persamaan regresi kedua $\mathrm{R}^{2}$ naik menjadi 0,705 atau 70,5 persen dengan tingkat signifikan 0,00< 0,05 yang menyatakan bahwa variabel kompetensi SDM berpengaruh signifikan terhadap kualitas LKPD yang dimoderasi oleh SPIP. Kesimpulannya dengan adanya SPIP akan dapat memperkuat pengaruh antara variabel kompetensi SDM terhadap kualitas LKPD.

Persamaan III $=$ LKPD $=a+b_{1} \mathrm{TI}+\mathrm{b}_{2}$ SPIP + $\mathrm{b}_{3}$ TI.SPIP $+\mathrm{e}$

Hasil uji hipotesis menunjukkan bahwa diketahui nilai thitung untuk variabel Pemanfaatan TI (X2) yang dimoderasi SPIP (Z) sebesar 2,223 sedangkan, nilai ttabel dengan taraf nyata (a) sebesar $0,05(5 \%)$ serta $\mathrm{df}=$ $\mathrm{n}-\mathrm{k}-1=108$ adalah sebesar 1,659. Jadi dapat disimpulkan bahwa Ha diterima dan Ho ditolak karena, nilai thitung $(2,223)>\mathrm{t}$ tabel $(1,659)$.

Hasil uji hipotesis individual untuk variabel pemanfaatan TI $\left(\mathrm{X}_{2}\right)$ menunjukkan bahwa variabel tersebut berpengaruh secara signifikan terhadap variabel kualitas LKPD (Y) yang dimoderasi variabel SPIP (Z). Hal ini digambarkan dengan nilai $\mathrm{R}^{2}$ pada regresi pertama sebesar 0,486 atau 48,6 persen sedangkan setelah ada persamaan regresi kedua $\mathrm{R}^{2}$ naik menjadi 0,775 atau 77,5 persen dengan tingkat signifikan 0,02 < 0,05 yang menyatakan bahwa variabel pemanfaatan TI berpengaruh signifikan terhadap kualitas LKPD yang dimoderasi oleh SPIP. Kesimpulannya dengan adanya SPIP akan dapat memperkuat pengaruh antara variabel pemanfaatan TI tehadap kualitas LKPD.

Persamaan IV $=$ LKPD $=a+b_{1}$ SAP $+b_{2}$ SPIP + $\mathrm{b}_{3}$ SAP.SPIP + e

Hasil uji hipotesis menunjukkan bahwa diketahui nilai $\mathbf{t}_{\text {hitung }}$ untuk variabel penerapan $\operatorname{SAP}\left(\mathrm{X}_{3}\right)$ yang dimoderasi kompleksitas tugas $\left(\mathrm{X}_{5}\right)$ sebesar 2,341 sedangkan, nilai t tabel dengan taraf nyata (a) sebesar $0,05(5 \%)$ serta $\mathrm{df}=\mathrm{n}-\mathrm{k}-1=108$ adalah sebesar 1,659 . Jadi dapat disimpulkan bahwa Ho diterima dan $\mathrm{Ha}$ ditolak karena, nilai $\mathbf{t}_{\text {hitung }} 2,341>\mathbf{t}_{\text {tabel }} 1,659$.

Hasil uji hipotesis individual untuk variabel penerapan SAP $\left(\mathrm{X}_{3}\right)$ menunjukkan bahwa variabel tersebut tidak berpengaruh secara signifikan terhadap variabel terikat (Y) yang dimoderasi variabel SPIP (Z). Hal ini digambarkan dengan nilai $\mathrm{R}^{2}$ pada regresi pertama sebesar 0,141 atau 14,1 persen sedangkan setelah ada persamaan regresi kedua $\mathrm{R}^{2}$ naik menjadi 0,755 atau 75,5 persen dengan tingkat signifikan 0,02 < 0,05 yang menyatakan bahwa variabel penerapan SAP berpengaruh signifikan terhadap kualitas LKPD yang dimoderasi oleh SPIP. Kesimpulannya dengan adanya SPIP akan dapat memperkuat pengaruh antara variabel penerapan SAP tehadap kualitas LKPD. 
Persamaan $\mathrm{V}=\mathrm{LKPD}=\mathrm{a}+\mathrm{b} 1 \mathrm{AI}+\mathrm{b} 2 \mathrm{SPIP}+$ b3AI.SPIP + e

Hasil uji hipotesis menunjukkan bahwa diketahui nilai $\mathbf{t}_{\text {hitung }}$ untuk variabel peran Audit Internal $\left(\mathrm{X}_{4}\right)$ yang dimoderasi SPIP $\left(\mathrm{X}_{5}\right)$ sebesar 1,366 sedangkan, nilai $\mathbf{t}_{\text {tabel }}$ dengan taraf nyata (a) sebesar $0,05(5 \%)$ serta $\mathrm{df}=$ $\mathrm{n}-\mathrm{k}-1=108$ adalah sebesar 1,659. Jadi dapat disimpulkan bahwa Ha diterima dan Ho ditolak karena, nilai $\mathbf{t}_{\text {hitung }}(1,366)<\mathbf{t}_{\text {tabel }}(1,659)$.

Hasil uji hipotesis individual untuk variabel peran Audit Internal (X4) menunjukkan bahwa variabel tersebut tidak berpengaruh secara signifikan terhadap variabel terikat $(Y)$ yang dimoderasi variabel SPIP $(\mathrm{Z})$.

Hal ini dapat dijelaskan karena Audit Intern tidak mengerjakan secara langsung dalam proses penyusunan dan penyajian LKPD. Tugas utama Audit Intern adalah melakukan pemerikasaan, pembinaan terhadap proses pelaporan keuangan pemerintah daerah dan sebagai konsultan manajemen. Keterbatasan jumlah aparat Inspektorat, tingkat kompetensi dan luasnya cakupan pemeriksaan masih menjadi kendala untuk dapat memeriksa seluruh pos keuangan secara cermat dan mendetail, sehingga kinerja audit intern menjadi kurang optimal. Selain itu, dari hasil penelitian ini juga dapat diketahui bahwa kemampuan audit intern dalam mendeteksi ketidakpatuhan, kesalahan/ penyimpangan belum optimal. Oleh karenanya kesalahan dalam kegiatan maupun dalam pencatatan akuntansi yang telah dilakukan tidak terdeteksi hingga saat pemeriksaan oleh BPK. Kesalahan tersebut misalnya dalam hal pengelolaan keuangan dan penilaian aset daerah. Hal ini terbukti dengan adanya temuan BPK yang tidak ditemukan sebelumnya oleh Audit Intern pemerintah.

\section{Pengaruh Kompetensi SDM terhadap Kualitas LKPD}

Hasil pengujian hipotesis pertama terdapat pengaruh positif dan signifikan Kompetensi SDM terhadap Kualitas LKPD di Pemerintah Kabupaten Banyuasin, artinya semakin tinggi kompetensi SDM suatu pemerintahan maka akan meningkatkan kualitas LKPD. Hasil penelitian ini sejalan dengan teori Stewardship dalam asumsi dasarnya facilitate and empower dimana penggunaan variabel tersebut diharapkan dapat memfasilitasi dan memberdayakan SDM yang kompeten untuk pengendalian internal menjadi efektif guna menghasilkan laporan keuangan yang berkualitas (Donaldson \& Davis, 1991 dalam Santoso, 2016).

Besarnya pengaruh langsung dari kompetensi SDM terhadap kualitas LKPD pada penelitian ini adalah sebesar 76,4 persen dan setelah dimoderasi oleh SPIP maka pengaruhnya bertambah sebesar 89,5 persen.

\section{Pengaruh Pemanfaatan TI terhadap Kualitas LKPD}

Hasil pengujian hipotesis dan analisis menunjukkan bahwa pemanfaatan TI berpengaruh positif dan signifikan terhadap kualitas LKPD, secara parsial pemanfaatan TI berpengaruh sebesar 69,7 persen dan secara moderasi oleh SPIP pengaruhnya diperkuat sebesar 88 persen. Hal ini menunjukkan bahwa teknologi informasi yang digunakan dalam menyusun laporan keuangan akan bertambah pengaruhnya karena adanya aturan yang dilakukan melalui SPIP dan dilakukan terus menerus.

\section{E. Pengaruh Penerapan SAP terhadap Kualitas LKPD}

Hasil pengujian hipotesis dan analisis menunjukkan bahwa penerapan SAP berpengaruh positif dan signifikan terhadap kualitas LKPD, secara parsial penerapan SAP berpengaruh sebesar 37,5 persen dan secara moderasi oleh SPIP pengaruhnya diperkuat sebesar 86,9 persen. Hal ini menunjukkan bahwa penerapan SAP dalam menyusun laporan keuangan akan bertambah pengaruhnya karena adanya aturan melalui SPIP dan dilakukan terus menerus. Dimensi yang paling dominan dalam membentuk penerapan SAP adalah tahap pencatatan.

\section{F. Pengaruh Peran Audit Internal terhadap Kualitas $L K P D$}

Hasil pengujian hipotesis dan analisis menunjukkan bahwa peran audit internal berpengaruh positif dan signifikan terhadap kualitas LKPD, secara parsial peran audit internal berpengaruh sebesar 69,4 persen dan secara moderasi oleh SPIP pengaruhnya diperkuat sebesar 87,3 persen.. Dimensi yang paling dominan dalam membentuk peran audit internal adalah independensi.

G. Pengaruh Kompetensi SDM, Pemanfaatan TI, Penerapan SAP, dan Peran Audit Internal terhadap Kualitas LKPD dengan SPIP sebagai Variabel Moderasi

Hasil pengujian hipotesis model kedua menunjukkan interaksi antara kompetensi SDM dengan SPIP memberikan nilai koefisien 2,064 dengan probabilitas signifikansi $0,042<0,05$. Temuan penelitian ini menunjukkan bahwa SPIP merupakan variabel moderasi yang memperkuat pengaruh kompetensi SDM terhadap kualitas LKPD. Artinya, semakin tinggi kompetensi SDM dengan SPIP yang tinggi maka semakin baik kualitas LKPD di Pemerintah Kabupaten Banyuasin.

Selanjutnya interaksi antara pemanfaatan TI dengan SPIP memberikan nilai koefisien 3,322 dengan probabilitas signifikansi $0,001<0,05$. Temuan penelitian ini menunjukkan bahwa SPIP merupakan variabel moderasi yang memperkuat pengaruh pemanfaatan TI terhadap kualitas LKPD. Artinya, semakin tinggi pemanfaatan TI dengan SPIP yang tinggi maka semakin baik kualitas LKPD di Pemerintah Kabupaten Banyuasin.

Kemudian interaksi antara penerapan SAP dengan SPIP memberikan nilai koefisien 1,224 dengan probabilitas signifikansi 0,224 >0,05. Temuan penelitian ini menunjukkan bahwa variabel SPIP tidak memperkuat pengaruh penerapan SAP terhadap kualitas LKPD. Artinya, penerapan SAP yang dimoderasi oleh SPIP tidak memengaruhi kualitas LKPD di Pemerintah Kabupaten Banyuasin.

Variabel terakhir yaitu interaksi antara peran Audit Internal dengan SPIP memberikan nilai koefisien 1,366 dengan probabilitas signifikansi $0,175>0,05$. Temuan 
penelitian ini menunjukkan bahwa SPIP bukan merupakan variabel moderasi yang memperkuat pengaruh peran Audit Internal terhadap kualitas LKPD. Artinya, peran audit internal yang dimoderasi SPIP bukanlah faktor yang akan meningkatkan kualitas LKPD di Pemerintah Kabupaten Banyuasin.

\section{Kesimpulan}

1. Kompetensi SDM secara parsial berpengaruh terhadap kualitas LKPD, begitu juga kompetensi SDM yang dimoderasi oleh SPIP berpengaruh signifikan terhadap kualitas LKPD hal ini sejalan dengan teori Stewardship dalam asumsi dasarnya facilitate and empower dimana penggunaan variabel tersebut diharapkan dapat memfasilitasi dan memberdayakan SDM yang kompeten untuk pengendalian internal menjadi efektif guna menghasilkan laporan keuangan yang berkualitas.

2. Pemanfaatan TI berpengaruh positif dan signifikan terhadap Kualitas LKPD, dan berpengaruh signifikan dengan dimoderasi oleh SPIP artinya semakin tinggi pemanfaatan TI yang digunakan akan semakin mendukung Kualitas LKPD pemerintah Kabupaten Banyuasin. Penelitian ini sesuai dengan teori stweradship yaitu collectivistic, pro-organizational, trustworthy yang menyatakan bahwa manajemen dan auditor internal secara kolektif (bersama-sama) dan kooperatif mengarahkan seluruh kemampuan dan kualitasnya dalam mengefektifkan dan memanfaatkan teknologi yang ada untuk menghasilkan laporan keuangan pemerintah daerah yang berkualitas.

3. Penerapan SAP tidak berpengaruh signifikan terhadap kualitas LKPD, namun penerapan SAP berpengaruh signifikan jika dimoderasi oleh SPIP. Hal ini sejalan dengan teori Model of man pada stewardship theory didasarkan pada steward (pelayan) yang memiliki tindakan kolektif atau berkelompok, bekerja sama dengan utilitas tinggi dan selalu bersedia untuk melayani, pemerintah dan auditor internal secara kolektif (bersama-sama) dan kooperatif mengarahkan seluruh kemampuan dan kualitasnya dalam mengefektifkan pengendalian internal dengan memanfaatkan teknologi yang ada serta penerapan SAP yang berlaku untuk menghasilkan laporan keuangan pemerintah daerah yang berkualitas.

4. Peran Audit Internal secara simultan berpengaruh positif dan signifikan terhadap kualitas LKPD, namun tidak berpengaruh signifikan jika dimoderasi oleh SPIP. Semakin tinggi Peran Audit Internal maka akan semakin mendukung Kualitas LKPD pemerintah Kabupaten Banyuasin, namun tidak akan berpengaruh jika dimoderasi oleh SPIP.

\section{Saran}

Penelitian ini diharapkan dapat dikembangkan dengan penelitian lanjutan pada kondisi yang berbeda dengan variabel yang lebih kompleks dengan populasi yang lebih besar, sehingga hasilnya dapat menyempurnakan penelitian ini. Langkah tersebut dapat dilakukan dengan menggali variabel-variabel lain yang dianggap penting dan dominan dengan dukungan teori yang lebih mendalam. Hasil penelitian diharapkan dapat memperkaya dan memberikan kontribusi bagi kepentingan praktis dan bagi pengembangan ilmu pengetahuan, khususnya ilmu akuntansi.

Bagi peneliti selanjutnya agar dapat melakukan pengujian dengan menambahkan variabel lain seperti sarana dan prasarana, komitmen pegawai, budaya organisasi, gaya kepemimpinan, motivasi aparatur, kapasitas auditor, independensi auditor, dan sistem pengawasan. Setiap satuan kerja hendaknya memiliki sumber daya yang kompeten dalam menjalankan tugastugas terutama dalam penerapan SAP dan SPIP karena berdasarkan hasil penelitian kebanyakan pegawai yang menjadi responden penelitian mengeluhkan masalah kurangnya pemahaman tentang SAP dan SPIP.

Bagi peneliti selanjutnya hendaknya membuat kuisioner yang baru dan disesuaikan dengan kondisi daerah yang diteliti sehingga dapat menggambarkan permasalahan yang sebenarnya.

\section{Daftar Pustaka}

Agustiawan, N. T \& Rasmini. 2016. Pengaruh Sistem Berbasis Akrual, TI, dan SPIP pada Kualitas Laporan Keuangan dengan Kompetensi SDM sebagai Moderasi. E-Jurnal Ekonomi dan Bisnis Universitas Udayana 5.10 (2016): 3475-3500. ISSN : 2337-3067.

Badan Pemeriksa Keuangan RI. 2016. Ikhtisar Hasil Pemeriksaan Semester I Tahun 2016. Jakarta.

Delanno, G. F \& Deviani. 2013. Pengaruh Kapasitas SDM, Pemanfaatan TI, dan Pengawasan Keuangan terhadap Nilai Informasi Laporan Keuangan Pemerintah Daerah. Jurnal WRA Vol. 1 No. 1. April 2013.

Hertati, L. 2015. "Competence of Human Resources, The Benefits of Information Technology on Value of Financial Reporting in Indonesia". Research Journal of Finance and Accounting. ISSN 22221697 (Paper) Vol. 6 No. 8.

Inapty, F \& Sri Pancawati Martiningsih. 2016. Pengaruh Penerapan Standar Akuntansi Pemerintahan, Kompetensi Aparatur dan Peran Audit Internal terhadap Kualitas Informasi Laporan Keuangan dengan Sistem Pengendalian Intern sebagai Variabel Moderating (Studi Empiris Pada SKPDSKPD di Pemprov. NTB). Jurnal Ilmu Akuntansi Volume 9 (1), April 2016 P-ISSN: 1979-858X; EISSN: 2461-1190 Page 27 - 42.

Indriasih, D. 2014. "The Effect of Government Apparatus Competence and the Effectiveness of Government Internal Control Toward the Quality of Financial Reporting in Local Government". Research Journal of Finance and Accounting. ISSN 2222-1697 (Paper) ISSN 2222-2847 (Online) Vol.5, 
No.20, 2014.

Kasim, E. Y. 2015. "Effect Of Government Accountants Competency And Implementation Of Internal Control To The Quality Of Government Financial Reporting". International Journal of Business, Economics and Law, Vol. 8, Issue 1 (Dec.) ISSN 2289-1552.

Kawedar, W. 2010. Opini Audit dan Sistem Pengendalian Intern (Studi Kasus di Kabupaten PWJ yang Mengalami Penurunan Opini Audit). Jurnal Akuntansi dan Auditing Vol. 11 No.1 , 7299.

Mardiasmo, 2009. Akuntansi Sektor Publik Edisi Ketiga. Yogyakarta : Penerbit Andi.

Republik Indonesia, Peraturan Pemerintah No. 60 Tahun 2008 tentang Sistem Pengendalian Intern Pemerintahan.

Republik Indonesia, Peraturan Pemerintah No. 65 Tahun 2010 tentang Sistem Informasi Keuangan Daerah.

Republik Indonesia, Peraturan Pemerintah No. 71 tahun 2010 tentang Standar Akuntansi Pemerintahan.

Republik Indonesia, Undang-Undang RI No. 17 Tahun 2003 tentang Keuangan Negara.

Republik Indonesia, Undang-Undang RI No.1 Tahun 2004 tentang Perbendaharaan Negara.

Republik Indonesia, Undang-Undang No. 15 Tahun 2004 tentang Pemeriksaan Pengelolaan dan Tanggung Jawab Keuangan Negara.

Sagara, Y. 2015. "The Effect of Implementation Accounting Information System and Competence of Human Resources on the Quality of Financial Reporting". Research Journal of Finance and Accounting. ISSN 2222-1697 (Paper) Vol. 6 No. 10.

Sudarmanto. 2009. Kinerja dan Penembangan Kompetensi Sumber Daya Manusia: Teori, Dimensi Pengukuran dan Implementasi dalam Organisasi. Yogyakarta: Pustaka Pelajar.

Thompson, Ronald L., 1994. Higgins, Christopher A., dan Howwel, Jane M., "Influence of Experience on Personal Computer Utilization: Testing A Conceptual Model," Journal of Management Information systems.

Tuanakotta, T. M. 2013. Audit Berbasis ISA (International Standards on Auditing). Jakarta : Salemba Empat.

Wahana Komputer. 2003. Konsep Jaringan Komputer dan Pengembangannya. Semarang: Salemba Infotek.

Warongan, Jessy Dimarcus L. et al. 2014. "The Effects of Effectiveness Mediation of Internal Control System on Competency of Human Resources and Audit Opinion in Previous Year toward Quality of Financial Statement". Quest Journals Journal of Research in Business and Management Volume 2 Issue 11 (2014) pp: 09-16 ISSN(Online) : 23473002 